\title{
The Faith Community and the SARS-CoV-2 Outbreak: Part of the Problem or Part of the Solution?
}

\author{
Jeff Levin ${ }^{1}$ \\ Published online: 2 June 2020 \\ ๑) Springer Science+Business Media, LLC, part of Springer Nature 2020
}

\begin{abstract}
The current outbreak of the SARS-CoV-2 virus is a critical moment in time for institutional religion in the USA and throughout the world. Individual clergy and congregations, across faith traditions, have been sources of misinformation and disinformation, promoting messages and actions that engender fear, animosity toward others, and unnecessary risk-taking. But there is a positive role for religion and faith-based institutions here, and many examples of leaders and organizations stepping up to contribute to the collective recovery. Personal faith and spirituality may be a source of host resistance and resilience. Religiously sponsored medical care institutions are vital to health care response efforts. Ministries and faith-based organizations are source of religious health assets that can help to meet community-wide needs. There is a pastoral role for clergy and laypeople who are instrumental in providing comfort and strength to the suffering and fearful in our midst. The outbreak presents an ethical challenge to all of us to step outside of our own preoccupations and to be present and of service for others. This includes having the courage to represent the highest values of our faith in speaking out against religiously motivated foolishness and hatred and in calling for political and public health leaders to be truthful and transparent in their messages to us.
\end{abstract}

Keywords COVID-19 $\cdot$ SARS-CoV-2 $\cdot$ Religion $\cdot$ Faith-based

As everyone is aware, we are in the midst of a global outbreak of an acute respiratory disease caused by the SARS-CoV-2 virus. While the general public may believe that it has an understanding of the parameters of the outbreak due to the constant stream of information circulating on the internet, in social media, on blogs, and in the mainstream news, most of this information is being misconveyed or is downright incorrect. Especially serious are the pronouncements and projections, most of

Jeff Levin

jeff_levin@baylor.edu

1 Institute for Studies of Religion, Baylor University, One Bear Place \# 97236, Waco, TX 76798, USA 
them alarming, originating with government officials and purported experts, including physicians, nearly none of whom have advanced training in epidemiology nor understand the nuances of infectious disease transmission. A lot of misinformation is being communicated regarding disease risk, the pathogenesis of infection, and the prognosis for diagnosed cases, and technical terms are being thrown around-exposure, case-fatality, herd immunity, transmission, incubation, and epidemic curveswithout an accurate understanding of what these terms mean and what current data imply. This is doing much to frighten the general public, and has led reflexively to community-wide lockdowns and other "extreme measures of unknown effectiveness" (Ioannidis 2020b).

Much of the existing confusion and uncertainty stem from widespread misunderstanding of the nature of the natural history of the present disease, which has been named COVID-19. Specifically, while exposure to the virus may be near ubiquitous, not everyone who is exposed becomes infected. Infectivity, in turn, does not inevitably lead to pathogenicity, to diagnosis with the signs and symptoms of disease. Nor are all clinical cases virulent enough to require medical care, and only a subset of those will require hospitalization. Finally, only a small subset of those, in turn, will be serious enough to require intensive care, and most will recover. Only a very small subset of a subset of a subset of exposures, therefore, will become fatalities, and these are primarily among the elderly or those with preexisting chronic or acute comorbidities, including obesity. Clearly, this message has not gotten out to the public in convincing fashion. Worse, political calculation is taking over in some quarters, such as at the World Health Organization (The Editorial Board 2020), which has refused to acknowledge the Chinese source of the outbreak (Gilsinian 2020) as well as the early warnings from Taiwanese health ministry officials (Culpan 2020).

The outbreak presents one sort of a challenge clinically, another for the health care sector, another for epidemiology. The typical clinical presentation of the most serious cases is well known by now (Lake 2020; Zhou et al. 2020), and is undeniably terrible and life-threatening. The burden on the health care system from the surge of hospitalized cases has stretched its intake capacity to a breaking point in some (but not all) nations (Kandel et al. 2020), endangering the ability to respond with adequate medical care (Emanuel et al. 2020). This, too, is understood by most people, both providers and the general population.

The bare bones of the epidemiologic parameters of the outbreak, however, are widely misconstrued. As a result, very sketchy messages have gone out to the public, including over-the-top pronouncements and projections about fatalities that do not make much epidemiologic sense or track with what we know about infectious disease transmission, and that serve only to scare the general public. Early guesstimates of case-fatality and the basic reproduction number ( or $R_{0}$ ), for example, suggested something historically catastrophic. Experts espousing more measured views were and still are labeled as "deniers" (Nelson and Osman 2020), baselessly lumping them in with extremists who believe the outbreak is a hoax or a conspiracy. On the other hand, the most recent estimates of the population prevalence of infection seem to place the infection-fatality rate for the current outbreak somewhere in the neighborhood of seasonal influenza, or a bit above or a bit below (Bailey 2020; Bendavid et al. 2020). However, this narrative has been resisted by the director of NIAID and 
the secretary general of the WHO, who have insisted, respectively, that the outbreak is ten times more lethal than both seasonal influenza (Fauci quoted in House Oversight and Reform Committee 2020) and swine flu (Tedros quoted in World Health Organization 2020).

In fairness to both sides, we still lack the requisite information on transmissibility and virulence to draw definitive conclusions. We do not yet have a conclusive grasp on basic parameters of the outbreak, such as the proportion of the population that is infected, the speed of transmission, the infection-fatality rate, how much immunity is conveyed by infection and its duration, the potential effectiveness of herd immunity, whether non-case (i.e., asymptomatic) infections are contagious, and whether outbreaks will become seasonal (Lessler quoted in Chotiner 2020, and summarized in "Hopkins Epidemiologist Recaps Both What We Have Learned And Still Don't Know About SARS-CoV-2" 2020). Accordingly, there remains a continuing need to separate the signal from the noise. The voices that seem to be in charge, including the de facto leaders of the national response in the USA who are behind the microphones most often, as well as their supporters in the mainstream media, have offered more noise than signal at times and tend to be more alarmist. They are neither epidemiologists nor virologists, and it shows. This is not in any way to question their earnestness or their motives, but they mostly lack the expertise required to convey consistently reliable epidemiologic information to the public.

In the meantime, more sober-and professionally credentialed-voices are marginalized and ignored (e.g., Gupta quoted in Cookson 2020; Arkin quoted in Horovitz 2020; Ioannidis 2020a; Lee 2020a, b; Levitt quoted in Mozingo 2020). Less alarmist projections are ridiculed in the mainstream media, with one former presidential speechwriter actually condemning efforts to mitigate panic (e.g., Noonan 2020). Questioning of the tacit narrative on our prior knowledge of the likely geographical origins of the outbreak and our longstanding awareness of status of a likely Chinese coronavirus reservoir as a "time bomb" (Cheng et al. 2007), on how much the current situation did or did not take epidemiologists by surprise (Nuttall and Dye 2013), and on potential treatments, such as a measured repurposing of chloroquine (Vincent et al. 2005), are being discouraged or derided. This is reinforced in news reporting which mostly presents the story of the outbreak via the most frightening anecdotes in order, presumably, to heighten viewership or online hits, and by social media and blogs and through clickbait. The unsurprising result has been to fashion an echo chamber that has raised the general climate to one of hysteria and overreaction.

The countercritique has shown a marked propensity to go off the rails. A case in point is New York Times, which after surveying all the dimensions of the global outbreak, including the scope of personal suffering and the barriers and delays in mounting a unified comprehensive response, identified the singular source of blame for the existence of the pandemic: evangelical Christians in the USA (Stewart 2020). The op-ed in question, titled, "The Road to Coronavirus Hell was Paved by Evangelicals," claimed that "America's incompetent response" to the outbreak was caused by "the science denialism" of "Christian nationalists" who support the present administration. Regarding these assertions, the article continued, "the consequences are too obvious to ignore"-so obvious, apparently, that they were not 
enumerated. The negative reaction to this screed was so immediate that within 2 days the Times altered the headline to read, "The Religious Right's Hostility to Science Is Crippling Our Coronavirus Response," and it is under that headline that the article remains archived, with no indication of the more inflammatory original title that was abandoned.

Confusion and panic are further fueled not just by misinformation but by disinformation. Media ordained experts speaking out when they do not fully understand what they are talking about when it comes to the parameters of infectious disease transmission are only part of the problem. Worse is the amplification of these messages by both reputable and disreputable media outlets. Like a game of Telephone gone awry, this positive feedback loop of erroneous and fear-inducing messaging fuels fevered reactions from the general public, including people of faith and from faith community leaders. These religious sources of misinformation especially confound the problem. This includes misinterpretations of the facts of the outbreak, misguided efforts to place blame, and bad advice based on sketchy and exegetically questionable preaching. All of this din has become a distraction, at best, and a contributor to social unrest and widespread psychological distress-and actual heightened risk - at worst.

Some religious implorations are offered in earnest but with even less of an understanding of the pathophysiology, natural history, prognosis, or risk profile of COVID-19 than the medical opinion leaders who barely have a handle on the situation. Other religious messages, however, are offered with malign intent, such as calls to ignore the primary-preventive recommendations of public health authorities and to willfully violate laws regarding social distancing and hygiene measures. Two cases in point: a Louisiana pastor who violated a state ban by holding Easter services for over 1000 congregants, one of whom (his attorney) subsequently died, claiming, "Satan and a virus will not stop us. God will shield us from all harm and sickness" (McKay 2020); and a Pentecostal evangelist who dismissed the outbreak as a scheme by Satan to exterminate elderly Christians and promote socialism (Stone 2020). Both ministers challenged their congregants to ignore public health warnings and to continue to gather in large public groups at church.

\section{Religion as Part of the Problem}

Worst of all are the popular prejudices fueled by distorted messages circulating within congregations and among people of faith. Evangelicals and conservative Christians "seem to be disproportionately fooled by conspiracy theories" (Stetzer 2020) - this from a preeminent evangelical leader writing recently in Christianity Today. These messages continue to multiply and undergo their own form of "antigenic drift" (mutation) and "antigenic shift" (recombination), metaphorically speaking, to borrow the language of genetic epidemiology. This phenomenon is responsible for all sorts of ugly downstream effects, from the dumb to the ridiculous to the cowardly.

First, the dumb. Churches and synagogues in many communities have refused to practice social distancing, insisting on holding public services even in jurisdictions 
where it has been forbidden by law. These have been mostly (but not exclusively) Pentecostal and fundamentalist churches and charedi (ultra-Orthodox) shuls and minyanim. Such actions are dumb and self-defeating because they put their own congregants and families and their wider neighborhoods and communities at heightened risk of exposure, infection, and disease. Among older congregants who are already at elevated risk, these decisions may be jeopardizing their life. In asserting that they are standing up for God, or resisting tyranny, or whatever other reasons, all that is being done by such clergy and congregations is to threaten their own physical well being. This represents a kind of Darwin-Award approach to the outbreak, writ large, but, tragically, the potential victims here are not just the pastor-perpetrators, but innocent and trusting congregants.

This phenomenon appears to be especially in play for the monotheistic faith traditions whose normative expression is focused on communal worship of an omnipotent and behaviorally demanding deity who, presumably, expects attendance at services. Accordingly, with respect to the refusal to modify God-given liturgies or cancel services or other public gatherings and the general resistance to preventive measures, the monotheisms appear to be equal-opportunity offenders. A recent story in The Economist details examples of Christians in the USA and South Korea continuing to hold densely packed worship services with pastors promising miraculous antiviral cures; charedi Jews in Israel resisting government efforts to place restrictions on public prayer gatherings and life cycle events; and Iraqi shia Muslims refusing to curtail meetings led by clerics preaching messages such as the outbreak being "a punishment for gay marriage" ("Living on a Prayer" 2020, 46).

Second, the ridiculous. Consider the televangelist Kenneth Copeland. A prominent megachurch pastor and prosperity gospel preacher from Ft. Worth, Texas, Copeland has been in the news lately for having declared that he was personally summoning the "wind of God" to destroy the coronavirus forever (Woodward 2020). In the early stages of the outbreak, he famously led his congregation and leadership in a group chant: "Wind, almighty, strong, south wind, Heat: Burn this thing, in the name of Jesus. I say, you bow your knees. You fall on your face." Accordingly, he assured the faithful, the outbreak would thus be over soon, and, in the meantime, they could receive a healing through continuing to attend services in person or through touching their television screens when he was preaching. He also demanded that God send "a vaccination immediately." This is fascinating, as Copeland has been at the forefront of the antivaxx movement due to the strident anti-vaccination sermons that he and his wife and daughter have preached for the past decade. His family even advocated against influenza vaccines ("Jesus himself gave us the flu shot") (Reigstad 2018) as well as the CDC's recommended child and adolescent immunization schedule. The subsequent reemergence and endemicity of measles in North Texas and throughout conservative evangelical communities in the USA are owed in large part to his ministry.

Other pastors in the USA have spread a variety of questionable messages, although without the immoderate excesses of Copeland. These include theologically provocative statements which are (a) eschatological, such that the outbreak portends the start of the Tribulation or the End Times (see My Faith Votes 2020); (b) theodical, such that the outbreak was given to us by God as a divine chastisement for our 
sins (see Abbott 2020); (c) apologetical, such that God has allowed this outbreak to happen, much as He allowed Job to suffer, in order to challenge us to renew our faith and better resist Satan or simply to remind us that he is Lord (Englehart 2020); or (d) soteriological, such that the tragedy of this outbreak provides an opportunity to evangelize frightened non-believers among the general population or those suffering with COVID-19, in order to win them to Christ (Roach 2020). Where some of us may see this crisis an opportunity to be of service to our brothers and sisters, others may see it as an opportunity to harvest souls and build ministries. To be clear, there is nothing intrinsically ignoble about the latter as a general aim, but at the present time it seems insensitive to consider this a top priority.

Third, the cowardly. An offshoot of the present outbreak in the USA has been scapegoating and acts of violence directed toward Asian Americans. Accurate estimates of the numbers of physical attacks and the total number of hate crimes are difficult to come by, for reasons related to definitions, surveillance, and reporting, as well as politicization of the issue in both directions. One member of Congress suggested at the end of March that there have been over 1000 incidents since the beginning of the outbreak, and that there were now 100 reports each day (Kelley 2020). Another estimate, by an Asian American civil rights organization, suggests that these numbers of low, and that there have been thousands of incidents including over 650 on 1 weekend in March (Kandil 2020). Bigotry and physical attacks are not the only indignities faced by Americans of Chinese or other Asian origin. Stories and blog posts are circulating on the Internet and in social media which conflate the Chinese government's complicity in the slow response to the outbreak-which is true-with conspiracies related to Asian immigration to the USA, foreign immigrants in general, the loss or furloughing of American jobs, Chinese ownership of USA government debt, and the build-the-wall meme, creating an ugly xenophobic synergy.

A pertinent question: Where is the church in all of this? Where are the religious leaders who should be speaking out against this forcefully and consistently, as during the Civil Rights Movement? Why have pastors and congregations and denominations and laypeople largely failed to find their prophetic voice and condemn these assaults? Yes, local faith-based groups have stepped up (e.g., "Community Statement Regarding Anti-Asian Racism Associated with Coronavirus" 2020), as have larger denominational organizations (e.g., MC USA Staff 2020). They are to be commended (Shellnutt 2020). But they are exceptions. This is a critical moment for institutional religion in the USA, and, in my opinion, the faith sector is mostly failing the test. Another question: Among those leaders who have neglected to speak out, what are they afraid of? Perhaps, they fear drawing the wrong kind of attention to themselves, putting themselves in harm's way, or jeopardizing their standing with their congregations. These are understandable apprehensions, but not acceptable excuses. Difficult times call for courageous expressions of obedience to God. This is part of what it means to step out in faith. As Paul implores Christians, "Take no part in the unfruitful works of darkness, but instead expose them" (Ephesians 5:11, RSV).

Moreover, it should go without saying that pathogenic agents are no respecters of the citizenship of a particular person or of the geographical boundary lines on maps. 
Closing a national border to immigrants will not prevent a virulent pathogen from crossing over into USA territory, by way of hitchhiking on arthropod or other biological vectors or on fomites or other vehicles of transmission. Further, treating ethnic Americans or non-citizen residents-who are already here-disrespectfully or with violent intent hardly minimizes the risk associated with an outbreak of disease. Such behavior is irrational and ungodly, and no religious congregation or leader or person of faith should be associated in any way with such bigotry.

Sadly, this sort of reaction seems as American as apple pie, if history is a guide. As I recently noted,

this is a predictable response to the desperate feeling that such unpredictable events prove that God has forsaken us, lifted his veil of protection over us, and abandoned us to the forces of the natural world. Rather than face the public health challenge rationally in an effort to find a solution, many folks seek to lash out and demonize the Other. In the present crisis, the Other is primarily the Asian-American community. In previous social and political crises in the USA, it was Muslims, and before that Mexican immigrants or gays or African Americans or Roman Catholics (Levin 2020).

In the face of such feelings of desperation and hopelessness, people look for someone to blame. More often than not, it is religious, racial, ethnic, cultural, or political minorities who are singled out-communities of people who more or less define the Other. Previous public health crises in the USA have led to stigmatization, hyperbolic verbal attacks, and even physical violence directed at Mexican immigrants (the Ebola cluster of 2014), homosexual men (the AIDS epidemic in the 1980s), Chinese laborers (the bubonic plague epidemic of 1900), and Irish Catholics (the cholera epidemics of the Nineteenth Century).

Globally, the most notorious examples are the genocidal pogroms against Jews throughout Europe during and following the Black Death, the Fourteenth Century plague pandemic caused by transmission of the $y$. pestis bacterium (Cohn-Sherbok 1992). Between one-third and half of the population of the continent perished during the pandemic, and in almost every country it was Jews who were blamed (e.g., for having poisoned wells) and who faced the most complete and persistent attempts to exterminate them until the Holocaust 500 years later (Cohn 2007).

Interestingly, historians are not united in their identification of an inherent link between outbreaks of disease and outbreaks of blame and hatred of the Other. Some have contended that the two "were rarely connected" directly (e.g., Cohn 2012), and that, in the case of the Black Death, the pandemic provided a convenient opportunity for social and political elites to fulfill their anti-Semitic ambitions. While I am not a historian, but rather an epidemiologist, I find this observation fascinating and wonder if this theme will be revisited in the coming years as we reflect back on how the current outbreak has played out.

Are these reactions the best that religion and faith have to offer at times like these? Are they an inevitable result when the faith sector encroaches on the territory of science? Do people of faith and faith-based organizations and institutions also have something positive to contribute to our collective effort to face the present challenge? Thankfully, the answer to this last question is yes. These contributions, 
and potential contributions, merit a wider airing, as they risk being drowned out by the din of more destructive expressions of religiousness.

\section{Religion as Part of the Solution}

Our response to the present outbreak, and to public health challenges big and small, has much to gain both from expressions of personal faith and from the functions of faith-based organizations. Individual believers can draw on religious resources that may strengthen them as well as motivate acts of service to others. Religious organizations, and their leaders, can fulfill their prophetic role in calling the world out of its sinful complacency and self-centeredness by addressing the moral obligation to be of service to fellow human beings facing uncertainty, fear, or suffering. Religion can be a force for good here, helping us to meet the many challenges presented by the outbreak and helping us to become restored to wholeness, individually and collectively.

First, faith may have direct effects on human physiology (Levin 2009), such as through strengthening host resistance (Levin 1996). The practice of religion, the cultivation of spirituality, and expressions of faith can enhance our resilience, physically and psychologically, and mitigate mood disorders such as depression and anxiety which have been known for many years to exacerbate illness and inhibit recovery through dampening our immune response (Herbert and Cohen 1993). Connecting the dots between "psychoneuroimmunology and the faith factor" (Koenig and Cohen 2002) has been a source of informed theoretical exploration for nearly two decades, and published research validating a significant linkage goes back even further (Koenig et al. 1997).

Second, religion, in general, and religious institutions, more specifically, can contribute to the national health care response effort and is doing so, although perhaps invisibly to much of the public. So many hospitals and medical-care systems are faith-branded, and part of larger networks (Levin 2016). For example, consider how many medical centers are branded with the words Baptist, Catholic, Methodist, Lutheran, Episcopalian, Presbyterian, Adventist, and so on. This means that these denominations are full partners in the effort to face the challenge of the current outbreak, and are invested in this work as a central feature of their ministries of service. These faith-based health care partnerships can be instrumental in managing the surge of cases, in meeting the requisite supply chain needs for equipment, and in providing experienced leadership for local community response efforts and even for global outreach (Idler and Kellehear 2017).

Third, ministries, missions, and other faith-based organizations are sources of tangible "religious health assets" that can help to address the surge in health care needs as well as the resource requirements in other human services (Gunderson and Cochrane 2012). The surge issue is not just about hospital beds and access to medical care; it is about shortages and access shortfalls in other goods and services, especially for already underserved or generally at-risk populations. These include people living alone, the elderly, those with financial challenges, individuals without the necessary tangible resources for sheltering in place-and those unfortunate souls 
who check all four boxes. Many humanitarian organizations are stepping up. These include the outreach arm of well-known Christian ministries, such as Franklin Graham's Samaritan's Purse international relief organization, which has constructed a field hospital in New York City (Ault 2020), and Joel Osteen's Lakewood Church in Houston, which has held emergency blood drives (Homer 2020). These efforts, two among a multitude, have received substantial pushback due to these groups' statements of faith, a poignant reminder that politically motivated attempts to demonize evangelicals are not just misguided and bigoted but counterproductive and perhaps life-threatening.

Fourth, there is a pastoral role here for all people of faith, not just for ordained clergy or the chaplaincy. Congregations can serve as sources of health-directed social support, especially for vulnerable populations such as older adults (Krause 2008). During times of crisis or disaster, pastors may serve as sources of reassurance and comfort (Roberts and Ashley 2012). They also may offer hopeful health-related messages (Levin 1986) both through online sermons and personal interactions. With the requisite knowledge, they may also serve as voices of reason among the din of misinformation, and as trusted "translators" of responsible medical information for their congregations. Communities of faith - clergy, congregational leaders, laypeople - are a vast and powerful resource for ministering to people, strengthening their spirit, and supporting their recovery, both personal and communal. Throughout the USA and across faiths, religious commentators have already observed "the generosity and compassion of people stepping up to take care of each other in so many different ways" (Silverman 2020). The take-home message here is not about religious faith as a source of magical healing or divine protection (although we should not disparage such a hopeful message), but about providing a resource for making us resilient enough to withstand the current challenge.

Fifth, the outbreak has presented us with a social-justice teaching moment and a natural experiment in moral theology. It represents a real-world field experience for acting on religiously grounded values, such as Catholic social teaching (Curran 2002) and the halachic mandate to serve as agents of healing (Shulchan Aruch, Yoreh Deah 336:1). Rabbi Elliot N. Dorff has described this as "a universal duty to heal others because we are all under the divine imperative to help God preserve and protect what is God's" (Dorff 1998, 26). The outbreak is also a reminder of our connectedness. Despite the discomfort, confusion, and other emotional distress that consume so many of us right now, occupying our thoughts and feelings, this is a prime opportunity for the larger faith community to focus on reinforcing our oneness and to downplay those things that appear to separate us, especially religious affiliations and creeds. We are especially challenged to stem the noxious tide of bigotry and hatred and violence that so often boils over during national crises. Each of them has a decision to make: be consumed by fear and an obsession with the personal adjustments that confront us, or turn our attention outward to others who may have more serious issues to deal with than we do. When this is over, the wise among us may look back at the outbreak with gratitude as a reminder of the imperative of the three theological virtues of pistis (faith), elpis (hope), and agape (charity or love) spoken of by Paul (1 Corinthians 13:13). These are religious messages that everyone, of all faiths, can help to evangelize. 
Finally, the religious community should be at the forefront of the call for governmental transparency. This should be so not just for the present infectious disease outbreak, but in general, consistent with the maxim that we "speak truth to power." With respect to the outbreak, a lack of consistently reliable information has led to so much of the angst and fear and confusion and hostility that has characterized the public response to this situation, including the terrible examples of religious misinformation and malfeasance. Who better to speak this truth than leaders of our faith communities. Without transparency, bad things can result, percolating up from the collective id, egged on by those clergy with a personal agenda. Without a careful and dispassionate examination of evidence, and an honest accounting to the public about what we know and do not know and about how well we are or are not prepared, we will continue "lurching from complacency to panic" (Gostin and Cathaoir 2018) every time we are confronted with the threat of new pathogen. According to Philip Jenkins, one of the world's foremost historians of global religion:

$[\mathrm{M}]$ aybe the most important lesson is one for governments and authorities, which is that transparency pays. Letting people have the maximum amount of information in the most honest possible way is crucial because if people are not told this they will do really stupid things, they will blame particular ethnic groups, racial groups, they will develop conspiracy theories, and the way to deal with this is to provide information and transparency and agencies and countries that don't do this need to be blamed and exposed (Jenkins quoted in Heft 2020).

Transparency, accountability, and truth-telling are religiously grounded and religiously mandated virtues (e.g., Exodus 20:16, Ephesians 4:25). These are also widely recognized as among the foundations of civil society (Armstrong 2005). Just as we should hold religious leaders to account for the misinformation they spread from the pulpit and for their silence in the face of bigotry, so too should people of faith and the faith sector in general hold secular leaders to account for any uninformed and alarmist pronouncements and projections that engender so much fear that it leaves the public terrified and emotionally unbalanced. It is this state of mind, individually and collectively, that produces hatred and violence, and it should be the role of religion to do what it can to minimize these tendencies, not exacerbate them.

In sum, the current outbreak offers each of us an opportunity to become a better and more compassionate person, consistent with the teachings of the great faith and wisdom traditions. Moreover, it provides all of us with ample motivation to work together for a more compassionate and responsive society that better lives up to the moral teachings of these same traditions.

In a recent essay, I posed the question, "When the postmortems are written, will this outbreak be viewed as a case study in religious hatred, persecution, violence, and general stupidity, or as an exemplar of faith-based cooperation and communal solidarity?" (Levin 2020). This is a personal choice facing each one of us. If we collectively choose to draw on the best that our religious teachings have to offer, then I am optimistic. If we allow ourselves to fall victim to charlatanism posing as religious truth, then the outbreak will have been a wasted opportunity for growth, for rethinking why we are here and for reordering our priorities. The suffering that 
comes with crises and tragedies, whether on an individual or a global scale, is challenging to endure and survive, but if we are able to keep our heads it gives us a doorway into a better life and a better world.

Acknowledgements This paper is based in part on "Religious Dimensions of Infectious Disease Outbreaks: A Conversation with Dr. Jeff Levin," the 18th Annual David B. Larson Memorial Lecture on Religion and Health, Duke University School of Medicine, Durham, NC, March 12, 2020, as well on the author's remarks in various media stories in the weeks since.

\section{Compliance with Ethical Standards}

Conflict of interest The author declares that he has no conflict of interest.

\section{References}

Abbott, M. C. (2020). Coronavirus and divine chastisement. Renew America (March 13). Retrieved April 24, 2020, from http://www.renewamerica.com/columns/abbott/200313.

Armstrong, E. (2005). Integrity, transparency and accountability in public administration: Recent trends, regional and international developments and emerging issues. New York: United Nations Department of Economic and Social Affairs.

Ault, N. (2020). Christian relief comes to Central Park. Wall Street Journal (April 5). Retrieved April 24, 2020 from https://www.wsj.com/articles/christian-relief-comes-to-central-park-11586111772.

Bailey, R. (2020). COVID-19 lethality not much different than flu, says new study. Reason (April 17). Retrieved April 24, 2020, from https://reason.com/2020/04/17/covid-19-lethality-not-much-diffe rent-than-flu-says-new-study/.

Bendavid, E., Mulaney, B., Sood, N., Shah, S., Ling, E., Bromley-Dulfano, R., et al. (2020). COVID-19 Antibody seroprevalence in Santa Clara County, California. MedRxiv (April 11). Retrieved April 24, 2020, from https://www.medrxiv.org/content/10.1101/2020.04.14.20062463v1.full.pdf.

Cheng, V. C. C., Lau, S. K. P., Woo, P. C. Y., \& Yuen, K. Y. (2007). Severe Acute Respiratory Syndrome coronavirus as an agent of emerging and reemerging infection. Clinical Microbiology Reviews, 20, 660-694.

Chotiner, I. (2020). What have epidemiologists learned about the coronavirus. The New Yorker (April 16). Retrieved on April 24, 2020, from https://www.newyorker.com/news/q-and-a/what-have-epide miologists-learned-about-the-coronavirus.

Cohn, S. K. (2007). The Black Death and the burning of Jews. Past and Present, 196, 3-36.

Cohn, S. K. (2012). Pandemics: Waves of disease, waves of hate from the Plague of Athens to A.I.D.S. Historical Research, 85, 535-555.

Cohn-Sherbok, D. (1992). The crucified Jew: Twenty centuries of Christian anti-Semitism. Grand Rapids, MI: William B. Eerdmans Publishing Co.

Community Statement Regarding Anti-Asian Racism Associated with Coronavirus. (2020). ADL Philadelphia regional office (March 31). Retrieved April 24, 2020, from https://philadelphia.adl.org/ news/community-statement-regarding-anti-asian-racism-associated-with-coronavirus/.

Cookson, C. (2020). Coronavirus may have infected half of UK population-Oxford study. Financial Times (March 24). Retrieved April 24, 2020, from https://www.ft.com/content/5ff6469a-6dd8-11ea89df-41bea055720b.

Culpan, T. (2020). Taiwan's viral success makes it harder to ignore. Bloomberg Opinion (April 5). Retrieved April 24, 2020, from https://www.bloomberg.com/opinion/articles/2020-04-05/taiwan-sadvance-on-who-in-covid-19-shows-its-place-in-world.

Curran, C. (2002). Catholic social teaching 1891-present: A historical, theological, and ethical analysis. Washington: Georgetown University Press.

Dorff, E. N. (1998). Matters of life and death: A Jewish approach to modern medical ethics. Philadelphia: Jewish Publication Society. 
Emanuel, E. J., Persad, G., Upshur, R., Thome, B., Parker, M., Glickman, A., et al. (2020). Fair allocation of scarce medical resources in the time of Covid-19. New England Journal of Medicine. https://doi. org/10.1056/nejmsb2005114.

Englehart, S. (2020). If God can stop this pandemic why doesn't he? Crosswalk.com (March 24). Retrieved April 24, 2020, from https://www.crosswalk.com/faith/spiritual-life/if-god-can-stop-thispandemic-why-doesnt-he.html.

Gilsinian, K. (2020). How China deceived the WHO. The Atlantic (April 12). Retrieved April 24, 2020, from https://www.theatlantic.com/politics/archive/2020/04/world-health-organization-blame-pande mic-coronavirus/609820//.

Gostin, L. O., \& Cathaoir, K. E. Ó. (2018). Lurching from complacency to panic in the fight against dangerous microbes: A blueprint for a common secure future. Emory Law Journal, 67, 337-396.

Gunderson, G. R., \& Cochrane, J. R. (2012). Religion and the health of the public: Shifting the paradigm. New York: Palgrave Macmillan.

Heft, E. (2020). A Baylor history scholar discusses trends between historical pandemics. Retrieved April 24, 2020, from https://www.kxxv.com/news/coronavirus/a-baylor-history-scholar-discusses-trend s-between-historical-pandemics.

Herbert, T. B., \& Cohen, S. (1993). Depression and immunity: A meta-analytic review. Psychological Bulletin, 113, 472-486.

Homer, M. (2020). Lakewood Church holding emergency blood drive to help with severe shortage. KHOU 11 (March 20). Retrieved on April 24, 2020, from https://www.khou.com/article/news/healt $\mathrm{h}$ /coronavirus/lakewood-church-holding-emergency-blood-drive-to-help-with-severe-shortage/2857a5b68d6-0952-424c-853f-078eeb1a60dc.

Hopkins Epidemiologist Recaps Both What We Have Learned And Still Don't Know About SARSCoV-2. (2020). EpiMonitor, 41(4): 9.

Horovitz, D. (2020). Israeli scientist: You're not going to see millions of people die from COVID-19. The Times of Israel (March 18). Retrieved April 24 from https://www.timesofisrael.com/israeli-scientistyoure-not-going-to-see-millions-of-people-die-from-covid-19/.

House Oversight and Reform Committee. (2020). User clip: Dr. Fauci Congressional hearing re: flu vs. COVID-19. House Oversight and Reform Committee hearing on coronavirus response, day 1. C-Span (March 13). https://www.c-span.org/video/?c4861057/user-clip-dr-fauci-congressionalhearing-re-flu-vs-covid-19.

Idler, E. L., \& Kellehear, A. (2017). Religion in public health-care institutions: U.S. and U.K. perspectives. Journal for the Scientific Study of Religion, 56, 234-240.

Ioannidis, J. P. A. (2020a). A fiasco in the making? As the coronavirus pandemic takes hold, we are making decisions without reliable data. STAT (March 17). Retrieved April 24, 2020, from https://www. statnews.com/2020/03/17/a-fiasco-in-the-making-as-the-coronavirus-pandemic-takes-hold-we-aremaking-decisions-without-reliable-data/.

Ioannidis, J. P. A. (2020b). Coronavirus disease 2019: The harms of exaggerated information and nonevidence-based measures. European Journal of Clinical Investigation, 50(4), e13222. Retrieved April 24, 2020, from https://onlinelibrary.wiley.com/doi/epdf/10.1111/eci.13222.

Kandel, N., Chungong, S., Omaar, A., \& Xing, J. (2020). Health security capacities in the context of COVID-19 outbreak: an analysis of International Health Regulations annual report data from 182 countries. Lancet, 395, 1047-1053.

Kandil, C. Y. (2020). Asian Americans report over 650 racist acts over last week, new data says. $N B C$ News (March 26). Retrieved April 24, 2020, from https://www.nbcnews.com/news/asian-america/ asian-americans-report-nearly-500-racist-acts-over-last-week-n1169821.

Kelley, A. (2020). Attacks on Asian Americans skyrocket to 100 per day during coronavirus pandemic. The Hill (March 31). Retrieved April 24, 2020, from https://thehill.com/changing-america/respect/ equality/490373-attacks-on-asian-americans-at-about-100-per-day-due-to.

Koenig, H. G., \& Cohen, H. J. (Eds.). (2002). The link between religion and heath: Psychoneuroimmunology and the faith factor. New York: Oxford University Press.

Koenig, H. G., Cohen, H. J., George, L. K., Hays, J. C., Larson, D. B., \& Blazer, D. G. (1997). Attendance at religious services, interleukin-6, and other biological parameters of immune function in older adults. International Journal of Psychiatry in Medicine, 27, 233-250.

Krause, Neal. (2008). Aging in the church: How social relationships affect health. West Conshohocken, PA: Templeton Foundation Press.

Lake, M. A. (2020). What we know so far: COVID-19 current clinical knowledge and research. Clinical Medicine Journal, 20, 124-127. 
Lee, J. (2020a). How deadly is the coronavirus? It's still far from clear. The Spectator (March 28). Retrieved April 24, 2020, from https:/www.spectator.co.uk/article/The-evidence-on-Covid -19-is-not-as-clear-as-we-think.

Lee, J. (2020b). How to understand-and report-figures for "Covid deaths." The Spectator (March 29). Retrieved April 24, 2020, from https://www.spectator.co.uk/article/how-to-understand-andreport-figures-for-covid-19-deaths-.

Levin, J. S. (1986). Roles for the Black pastor in preventive medicine. Pastoral Psychology, 35, 94-103.

Levin, J. S. (1996). How religion influences morbidity and health: Reflections on natural history, salutogenesis and host resistance. Social Science and Medicine, 43, 849-864.

Levin, J. (2009). How faith heals: A theoretical model. EXPLORE: The Journal of Science and Healing, 5, 77-96.

Levin, J. (2016). Partnerships between the faith-based and medical sectors: Implications for preventive medicine and public health. Preventive Medicine Reports, 4, 344-350.

Levin, J. (2020). Religion confronts the COVID-19 outbreak. Berkley Forum (April 13). Retrieved April 24, 2020, from https://berkleycenter.georgetown.edu/responses/religion-confronts-thecovid-19-outbreak.

Living on a prayer. (2020). The Economist (April 11), 45-46.

MC USA Staff. (2020). Mennonite Church USA statement on anti-Asian racism and COVID-19. Mennonite Church USA (April 2). Retrieved April 24, 2020, from http://mennoniteusa.org/menno -snapshots/mc-usa-statement-anti-asian-racism-covid-19/.

McKay, R. (2020). Some defiant U.S. churches plan Easter services, ignoring public health guidelines. Reuters (April 10). Retrieved April 24, 2020, from https://www.reuters.com/article/us-healt h-coronavirus-easter-usa/some-defiant-us-churches-plan-easter-services-ignoring-public-healt h-guidelines-idUSKCN21S10Y.

Mozingo, J. (2020). Why this Nobel laureate predicts a quicker coronavirus recovery: "We're going to be fine." Los Angeles Times (March 23). Retrieved April 24, 2020, from https://www.latim es.com/science/story/2020-03-22/coronavirus-outbreak-nobel-laureate.

My Faith Votes. (2020). Q\&A with Dr. David Jeremiah: COVID-19, End Times prophecy, Rapture, Christ's return. The Christian Post (April 9). Retrieved April 24, 2020, from https://www.chris tianpost.com/voices/qa-with-dr-david-jeremiah-covid-19-end-times-prophecy-rapture-christsreturn.html.

Nelson, W., \& Osman, M. (2020). Sociological and psychological insights behind predicted changes as a result of COVID-19. PsyArXiv (April 5). https://doi.org/10.31234/osf.io/s5jkh.

Noonan, P. (2020). "Don't panic" is rotten advice. Wall Street Journal (March 12). Retrieved April 24, 2020, from https://www.wsj.com/articles/dont-panic-is-rotten-advice-11584054431.

Nuttall, I., \& Dye, C. (2013). The SARS wake-up call. Science, 339, 1287-1288.

Reigstad, L. (2018). A Texas televangelist says you don't need a flu shot if you've got Jesus. Texas Monthly (February 6). Retrieved April 24, 2020, from https://www.texasmonthly.com/news/texas -televangelist-says-dont-need-flu-shot-youve-got-jesus/.

Roach, D. (2020). Coronavirus searches lead millions to hear about Jesus. Christianity Today (April 7). Retrieved April 24, 2020, from https://www.christianitytoday.com/news/2020/april/coron avirus-searches-online-converts-pray-cru-bgea-wmo.html.

Roberts, S. B., \& Ashley, W. W. C., Sr. (Eds.). (2012). Disaster spiritual care: Practical clergy responses to community, regional and national tragedy. Woodstock, VT: Skylight Paths.

Shellnutt, K. (2020). Asian Americans call on the church to preach against coronavirus racism. Christianity Today (March 31). Retrieved April 24, 2020, from https://www.christianitytoday.com/ news/2020/march/asian-american-christian-statement-coronavirus-racism.html.

Silverman, G. (2020). Local scholar finds wisdom in Mi Shebeirach, the Jewish prayer for healing. Arizona Jewish Post (April 17). Retrieved April 17, 2020, from https://azjewishpost.com/2020/ local-scholar-finds-wisdom-in-mi-shebeirach-the-jewish-prayer-for-healing/.

Stetzer, E. (2020). On Christians spreading corona conspiracies: Gullibility is not a spiritual gift. Christianity Today Blog Forum (The Exchange) (April 15). Retrieved April 24, 2020, from https ://www.christianitytoday.com/edstetzer/2020/april/christians-and-corona-conspiracies.html.

Stewart, K. (2020). The road to coronavirus hell was paved by evangelicals. New York Times (March 27). Retrieved April 24, 2020, from https://web.archive.org/web/20200327092121/https://www. nytimes.com/2020/03/27/opinion/coronavirus-trump-evangelicals.html. 
Stone, M. (2020). Pastor claims coronavirus is satanic plot to bring socialism to the U.S. Patheos (March 13). Retrieved April 24, 2020, from https://www.patheos.com/blogs/progressivesecularhumanis t/2020/03/pastor-claims-coronavirus-is-satanic-plot-to-bring-socialism-to-the-u-s/.

The Editorial Board. (2020). World Health coronavirus disinformation. Wall Street Journal (April 5). Retrieved April 24, 2020, from https://www.wsj.com/articles/world-health-coronavirus-disinforma tion-11586122093.

Vincent, M. J., Bergeron, E., Benjannet, S., Erickson, B. R., Rollin, P. E., Ksiasek, T. G., et al. (2005). Chloroquine is a potent inhibitor of SARS coronavirus infection and spread. Virology Journal. https ://doi.org/10.1186/1743-422X-2-69.

Woodward, A. (2020). Coronavirus: Televangelist Kenneth Copeland "blows wind of God" at Covid-19 to "destroy" pandemic. Independent (April 5). Retrieved April 24, 2020, from https://www.indep endent.co.uk/news/world/americas/kenneth-copeland-blow-coronavirus-pray-sermon-trump-telev angelist-a9448561.html.

World Health Organization. (2020). COVID-19 virtual press conference-13 April, 2020. World Health Organization (April 13). Retrieved April 24 from https://www.who.int/docs/default-source/coron aviruse/transcripts/who-audio-emergencies-coronavirus-press-conference-13apr2020.pdf?sfvrs $\mathrm{n}=3 \mathrm{~d} 574 \mathrm{~d} 9 \mathrm{e} \_2$.

Zhou, F., Yu, T., Du, R., Fan, G., Liu, Y., Liu, Z., et al. (2020). Clinical course and risk factors for mortality of adult inpatients with COVID-19 in Wuhan, China: A retrospective cohort study. Lancet, 395, 1054-1062.

Publisher's Note Springer Nature remains neutral with regard to jurisdictional claims in published maps and institutional affiliations. 